\title{
Long-Term Follow-Up of Persistent Truncus Arteriosus: Kuwait Experience
}

\author{
J.P. Selvan ${ }^{\text {a }}$ B. Uthaman ${ }^{\text {b }}$ L. Abushaban ${ }^{c} \quad$ M.A. Qabandi ${ }^{\text {a }}$ A. Al Hay ${ }^{\text {a }}$ \\ A. Al Hassan ${ }^{a}$ M. Thinakarvel ${ }^{a}$

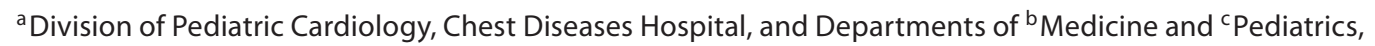 \\ Faculty of Medicine, Kuwait University, Kuwait City, Kuwait
}

\section{Key Words}

Persistent truncus arteriosus - Common arterial trunk •

Homograft reconstruction $\cdot$ Conduit repair

\begin{abstract}
Objective: To evaluate the long-term results of patients in Kuwait who were operated for persistent truncus arteriosus (PTA). Subjects and Methods: The following data were collected for retrospective analysis from 24 medical records of consecutive patients with PTA in Kuwait between August 1993 and August 2009: demographics, morphology, management and outcome. Major associated abnormalities included interrupted aortic arch in 1 patient and abnormal coronary artery anatomy in 2. Results: Of the 24 patients, 16 underwent total intracardiac repair. The age at operation ranged from 15 days to 5 years (mean $166.19 \pm 438.63$ days) and weight ranged from 2.5 to $15 \mathrm{~kg}$ (mean $4.3 \pm 3.01 \mathrm{~kg}$ ). The right ventricle to pulmonary artery continuity was established with aortic homograft in 11, pulmonary homograft in 4 and by implantation of a Contegra conduit in 1 patient. Four patients had moderate truncal valve regurgitation requiring concomitant truncal valve repair. After a mean follow-up period of $81.81 \pm 61.58$ months (range 3-166) there was no death. Eight of the 16 (50\%) patients underwent redo homograft operations. One patient who had concomitant truncal valve repair subsequently underwent aortic valve re-
\end{abstract}

placement. Conclusion: The data showed that complete repair of PTA in the neonatal and early infancy period was the treatment with the best potential for survival. The homograft remained one of the conduits of choice to establish continuity between the right ventricle and the pulmonary artery in spite of the high incidence of conduit redo operations.

Copyright $\odot 2011$ S. Karger AG, Basel

\section{Introduction}

Persistent truncus arteriosus (PTA) also known as common arterial trunk is best described as a congenitally malformed heart with normal atrial arrangement and concordant atrioventricular connections in which a solitary arterial trunk arises from the base of the heart and supplies the coronary, pulmonary and systemic arteries [1]. It accounts for $1.2-3 \%$ of all congenital heart malformations. This malformation is eventually fatal if not treated. The mean age of death is 2.5 months with $80 \%$ of affected children dead by 1 year of age [2]. The definitive treatment of PTA is surgery. The physiologic correction of PTA was described by McGoon et al. [3] in 1968. Since then, surgical correction during infancy has become possible. Here we report our long-term follow-up experience of patients with surgical repair of PTA. 
Table 1. Demographic and clinical data of the study group

\begin{tabular}{|c|c|c|c|c|c|c|c|c|c|c|c|c|c|c|}
\hline $\begin{array}{l}\text { Case } \\
\text { No. }\end{array}$ & $\begin{array}{l}\text { Year } \\
\text { of } \\
\text { birth }\end{array}$ & $\begin{array}{l}\text { Age at } \\
\text { presen- } \\
\text { tation }\end{array}$ & $\begin{array}{l}\text { Age at } \\
\text { opera- } \\
\text { tion }\end{array}$ & Sex & $\begin{array}{l}\text { Weight } \\
\text { at opera- } \\
\text { tion, kg }\end{array}$ & $\begin{array}{l}\text { Van } \\
\text { Praagh } \\
\text { classifi- } \\
\text { cation }\end{array}$ & $\begin{array}{l}\text { Truncal } \\
\text { valve leaflet }\end{array}$ & $\begin{array}{l}\text { Truncal } \\
\text { valve } \\
\text { regur- } \\
\text { gitation }\end{array}$ & \multicolumn{3}{|c|}{ Clinical symptoms } & $\begin{array}{l}\text { Associated } \\
\text { cardiac } \\
\text { anomaly }\end{array}$ & $\begin{array}{l}\text { Associated } \\
\text { noncardiac } \\
\text { anomaly }\end{array}$ & Outcome \\
\hline 1 & 1992 & 9 days & 22 days & $\mathrm{F}$ & 3 & $\mathrm{~A} 1$ & tricuspid & mild & + & - & - & - & - & operated \\
\hline 2 & 1994 & 9 days & expired & $\mathrm{F}$ & - & $\mathrm{A} 2$ & tricuspid & mild & + & - & - & ASD & - & expired \\
\hline 3 & 1994 & 45 days & 68 days & $\mathrm{F}$ & 3.1 & $\mathrm{~A} 1$ & tricuspid & mild & + & - & + & - & - & operated \\
\hline 6 & 1995 & 23 days & 29 days & M & 2.9 & A2 & tricuspid & mild & + & + & - & $\begin{array}{l}\text { abnormal } \\
\text { coronaries }\end{array}$ & - & operated \\
\hline 7 & 1995 & 5 months & 5 months & $\mathrm{F}$ & 4.8 & $\mathrm{~A} 2$ & quadricuspid & mild & + & + & + & - & - & operated \\
\hline 8 & 1996 & 11 days & 60 months & $\mathrm{M}$ & 15 & A3 & tricuspid & mild & + & + & + & PDA & G6PD deficiency & operated \\
\hline 9 & 1996 & 12 days & 21 days & $\mathrm{M}$ & 3.4 & A3 & $\begin{array}{l}\text { bicuspid and } \\
\text { dysplastic }\end{array}$ & mod. & + & - & - & $\begin{array}{l}\text { IAA type A, } \\
\text { PDA }\end{array}$ & - & operated \\
\hline 12 & 1998 & 7 days & 1 month & $\mathrm{F}$ & 3.5 & $\mathrm{~A} 1$ & tricuspid & mod. & + & + & - & - & - & operated \\
\hline 13 & 1999 & 7 days & 17 days & $\mathrm{M}$ & 3.4 & A1 & tricuspid & mild & + & - & - & $\begin{array}{l}\text { RAA, RPA } \\
\text { stenosis }\end{array}$ & - & operated \\
\hline 14 & 2002 & 1 year & $\begin{array}{l}\text { not } \\
\text { operated }\end{array}$ & $\mathrm{F}$ & - & $\mathrm{A} 1$ & tricuspid & mild & + & + & + & PDA & - & $\begin{array}{l}\text { not } \\
\text { operated }\end{array}$ \\
\hline 15 & 2004 & 1 day & $\begin{array}{l}\text { not } \\
\text { operated }\end{array}$ & $\mathrm{F}$ & - & $\mathrm{A} 1$ & tricuspid & nil & + & + & - & - & - & $\begin{array}{l}\text { not } \\
\text { operated }\end{array}$ \\
\hline 16 & 2004 & 1 day & expired & $\mathrm{M}$ & - & A2 & $\begin{array}{l}\text { bicuspid and } \\
\text { dysplastic }\end{array}$ & mild & + & + & - & RAA & - & expired \\
\hline 17 & 2005 & 24 days & 28 days & $\mathrm{F}$ & 2.5 & $\mathrm{~A} 1$ & quadricuspid & mod. & + & - & - & - & hydronephrosis & operated \\
\hline 18 & 2006 & 1 day & expired & $\mathrm{F}$ & - & A4 & tricuspid & nil & + & - & - & - & - & expired \\
\hline 24 & 2008 & 2 months & 6 months & $\mathrm{M}$ & 5.4 & $\mathrm{~A} 1$ & tricuspid & mild & + & + & + & - & G6PD defic & operated \\
\hline
\end{tabular}

$\mathrm{CHF}=$ Congestive heart failure; $\mathrm{FTT}=$ failure to thrive; $\mathrm{ASD}=$ atrial septal defect; mod. = moderate; $\mathrm{PDA}=$ patent ductus arteriosus; $\mathrm{RAA}=$ right aortic arch; RPA = right pulmonary artery; $\mathrm{MVP}=$ mitral valve prolapse; $\mathrm{PA}=$ pulmonary artery.

\section{Subjects and Methods}

The medical records of a group of 24 consecutive infants from Kuwait, who underwent corrective repair of PTA from August 1993 to June 2009, were reviewed (table 1). All patients were diagnosed by two-dimensional cross-sectional and colour Doppler echocardiography. In 7 patients preoperative cardiac catheterization was performed for better characterization of the diagnosis. The patients were classified according to Van Praagh classification (fig. 1): type $\mathrm{A} 1=16$ patients; type $\mathrm{A} 2=5$ patients; type $\mathrm{A} 3=2$ patients and type $\mathrm{A} 4=1$ patient. The truncal valve leaflets were bicuspid and dysplastic in 3 , tricuspid in 14 and quadricus- pid in 7 patients. Mild truncal valve regurgitation was present in 18 and moderate regurgitation in 4 patients. Moderate truncal valve regurgitation was associated with 1 patient with bicuspid dysplastic valve, 1 with tricuspid valve and 2 with quadricuspid valve. Coronary abnormalities were observed in 2 patients in our series. The mean age at presentation was $38.13 \pm 77.31$ days (range 1-365). Six patients died while waiting for surgery, 1 due to extreme prematurity and the others due to fulminant sepsis, necrotizing enterocolitis and disseminated intravascular coagulation. The parents of 2 infants did not accept surgery for their babies and returned to their native countries. The ventricular septal defect was closed with a patch in all of them through a right ven- 
Fig. 1. Van Praagh classification of PTA (courtesy: Children's Hospital, Boston, Mass., USA).

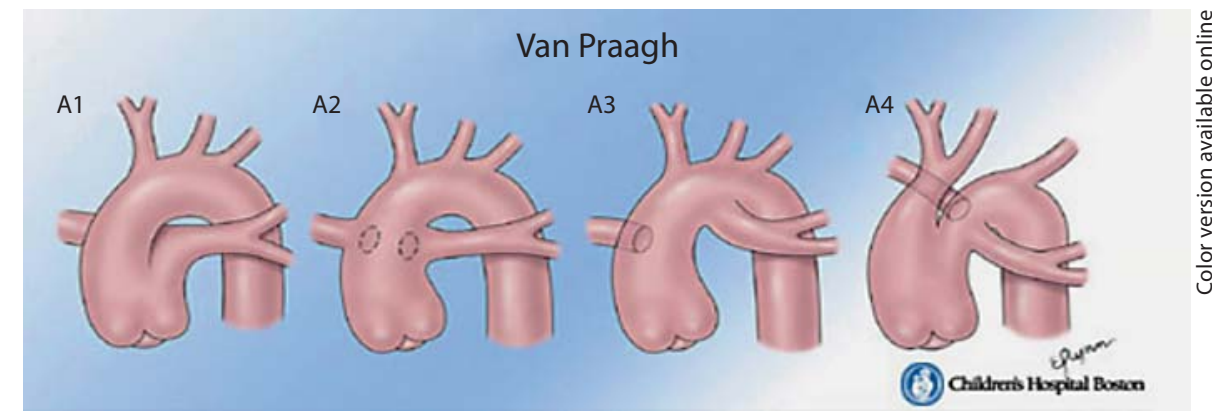

triculotomy and then a homograft was anastamosed first to the main pulmonary artery or its branches and then to the right ventriculotomy. The assessment of the functional result and capacity was performed in surviving patients by clinical, radiological, electrocardiographic and cross-sectional echocardiographic and colour flow Doppler examinations.

\section{Results}

Of the 24 patients, 16 (66.66\%) underwent surgical repair. The details of results are described in tables 1 and 2 . The mean age at operation was $166.19 \pm 438.63$ days (range 15-1,825). Nine patients were operated before 1 month of age, 4 between 1 and 3 months, 1 each at 5, 6 and 60 months, respectively. One patient was diagnosed initially as pulmonary atresia with ventricular septal defect and a right modified Blalock-Taussig shunt was performed at 18 months of age. Later at 5 years of age, it was recognized during surgery as type A3 PTA and corrective surgery was done. The mean weight at operation was $4.3 \pm 3.01 \mathrm{~kg}$ (range 2.5-15). The mean size of the original conduit used was $11.87 \pm 1.93 \mathrm{~mm}$ (range 10-18). Of the 16 patients, $11(68.7 \%)$ had an aortic homograft, while $4(25 \%)$ had a pulmonary homograft. One $(6.25 \%)$ patient had implantation of a Contegra conduit between the right ventricle and pulmonary artery. One patient with associated interrupted aortic arch (IAA) underwent simultaneous aortic arch repair.

There was no death in the postoperative period. These 16 patients had a mean follow-up period of $81.81 \pm 61.58$ months (range 3-166). Eight patients (50\%) underwent redo homograft replacement at 10, 24, 27, 50, 105, 143, 144 and 166 months (mean $83.63 \pm 62.9$ months; range 10 $166)$ after the initial operation. Two (25\%) had a pulmonary homograft in the first operation while $6(75 \%)$ had aortic homograft. Seven of them had moderate to severe homograft stenosis with a gradient above $50 \mathrm{~mm} \mathrm{Hg}$ pri- or to replacement. Four patients had moderate or more truncal valve regurgitation and underwent concomitant valve repair during the initial corrective surgery. The regurgitation was persistently severe in 1 patient and this child had his truncal valve replaced with St. Jude Medical valve prosthesis at 9 years of age. Seven of the remaining 8 patients who survived with the first homograft had mild homograft stenosis and 1 had no stenosis at last follow-up. Amongst the 16 patients who had initial surgery, mild homograft regurgitation was found in 11 (68.75\%) and moderate regurgitation in $2(12.5 \%)$. One patient (6.25\%) had moderate aortic valve (previous truncal valve) regurgitation while 8 (50\%) patients had mild aortic regurgitation and $3(18.75 \%)$ had mild aortic stenosis. The left ventricular systolic function was normal (ejection fraction more than 60\%) in all those followed up. Thirteen of the $16(81.25 \%)$ patients who were followed up had symptoms of NYHA class 1, 2 (12.5\%) of class 2 and $1(6.25 \%)$ of class 3 . All school-age children attend normal school.

\section{Discussion}

The follow-up of patients undergoing physiologic correction showed that a high percentage suffered from pulmonary vascular disease, which occurs at a fairly young age in the majority of patients with PTA [4]. A policy of early complete correction of symptomatic infants with PTA was adopted in 1974 [5]. Severe truncal valve regurgitation, IAA, coronary artery anomalies and age at repair greater than 100 days were important risk factors for perioperative death [6]. The 4 children in this study who were more than 100 days of age at the time of initial corrective surgery, 2 with coronary artery abnormalities and the only child with associated type A IAA, did well on follow-up. One-stage repair of both PTA and IAA is the optimal management [7]. 
Table 2. Findings of postoperative follow-up

\begin{tabular}{|c|c|c|c|c|c|c|c|}
\hline $\begin{array}{l}\text { Case } \\
\text { No. }\end{array}$ & Conduit and size used & $\begin{array}{l}\text { Concomitant heart } \\
\text { surgery }\end{array}$ & Associated morbidity & $\begin{array}{l}\text { Conduit } \\
\text { replacement }\end{array}$ & $\begin{array}{l}\text { Time after } \\
\text { initial } \\
\text { surgery, } \\
\text { months }\end{array}$ & $\begin{array}{l}\text { Follow- } \\
\text { up } \\
\text { period, } \\
\text { months }\end{array}$ & $\begin{array}{l}\text { Last NYHA } \\
\text { status }\end{array}$ \\
\hline 1 & $\begin{array}{l}\text { 12-mm pulmonary } \\
\text { homograft }\end{array}$ & - & mod. HG stenosis, mild AR & $\begin{array}{l}21-\mathrm{mm} \text { aortic } \\
\text { homograft }\end{array}$ & 144 & 159 & 1 \\
\hline 3 & 12-mm aortic homograft & truncal valve repair & mod. HG stenosis, Mod. AR & $\begin{array}{l}\text { 21-mm aortic } \\
\text { homograft }\end{array}$ & 24 & 144 & $\begin{array}{l}1 \text { and after } \mathrm{AV} \\
\text { replacement }\end{array}$ \\
\hline 4 & $\begin{array}{l}\text { 10-mm pulmonary } \\
\text { homograft }\end{array}$ & truncal valve repair & $\begin{array}{l}\text { temporary CHB, mild AR, } \\
\text { mild Hg Reg }\end{array}$ & - & - & 3 & $\begin{array}{l}2 \text { and lost to } \\
\text { follow-up }\end{array}$ \\
\hline 5 & 11-mm aortic homograft & - & mod. HG stenosis, mild HG Reg & $\begin{array}{l}\text { 17-mm aortic } \\
\text { homograft }\end{array}$ & 50 & 144 & 1 \\
\hline 6 & 12-mm aortic homograft & - & $\begin{array}{l}\text { mild AR, mild HG stenosis, } \\
\text { mild HG Reg }\end{array}$ & - & - & 3 & $\begin{array}{l}1 \text { and lost to } \\
\text { follow-up }\end{array}$ \\
\hline 7 & $\begin{array}{l}\text { 10-mm pulmonary } \\
\text { homograft }\end{array}$ & - & $\begin{array}{l}\text { mod. HG stenosis, } \\
\text { mild HG Reg, mild AR }\end{array}$ & $\begin{array}{l}\text { 18-mm Hancock } \\
\text { valved conduit }\end{array}$ & 143 & 146 & 1 \\
\hline 8 & $\begin{array}{l}\text { 18-mm aortic homograft } \\
\text { at } 60 \text { months }\end{array}$ & $\begin{array}{l}\text { removing of previous } \\
\text { BT shunt at } 18 \text { months }\end{array}$ & mod. HG stenosis, mild HG Reg & $\begin{array}{l}\text { 21-mm pulmonary } \\
\text { homograft }\end{array}$ & 166 & 166 & 1 \\
\hline 9 & 11-mm aortic homograft & $\begin{array}{l}\text { truncal valve repair } \\
+ \text { aortic arch repair }\end{array}$ & $\begin{array}{l}\text { SVT, sepsis, mild HG stenosis } \\
\text { and Reg }\end{array}$ & - & - & 42 & 1 \\
\hline 10 & 11-mm aortic homograft & - & mod. HG stenosis, mild AR, CHF & $\begin{array}{l}\text { 21-mm pulmonary } \\
\text { homograft }\end{array}$ & 105 & 108 & 3 \\
\hline 11 & 10-mm aortic homograft & - & $\begin{array}{l}\text { SVT, mild AR, mild HG stenosis, } \\
\text { mod. HG Reg }\end{array}$ & $\begin{array}{l}11-\mathrm{mm} \text { porcine } \\
\text { valved conduit }\end{array}$ & 10 & 75 & 2 \\
\hline 12 & 12-mm aortic homograft & truncal valve repair & $\begin{array}{l}\text { mild HG stenosis, mild AR, } \\
\text { mod. HG Reg }\end{array}$ & - & - & 132 & 1 \\
\hline 13 & 12-mm aortic homograft & - & $\begin{array}{l}\text { mod. HG stenosis, mild HG Reg, } \\
\text { mild AR }\end{array}$ & $\begin{array}{l}\text { 21-mm pulmonary } \\
\text { homograft }\end{array}$ & 27 & 88 & 1 \\
\hline 17 & 11-mm aortic homograft & - & mild HG stenosis, mild HG Reg, mild AS & - & - & 8 & 1 \\
\hline 20 & 12-mm aortic homograft & - & mild HG Reg, mild HG stenosis & - & - & 58 & 1 \\
\hline 23 & $\begin{array}{l}\text { 12-mm pulmonary } \\
\text { homograft }\end{array}$ & - & mild Hg stenosis, mild HG Reg, mild AS & - & - & 25 & 1 \\
\hline 24 & 14-mm Contegra conduit & - & mild HG stenosis, mild HG Reg, mild AS & - & - & 8 & 1 \\
\hline
\end{tabular}

Only 1 patient in this study had implantation of Contegra conduit consistent with the recommendation of Gober et al. [8] not to routinely use Contegra valved conduit for reconstruction of the right ventricular outflow tract because of an unpredictable incidence of supravalvar stenosis during midterm results. However, the child was still doing well with the initial surgery. Cryopreserved homograft conduits are generally preferred for the initial repair due to their ease of implantation and low incidence of conduit stenosis [9]. The majority of the patients $(93.75 \%)$ in this study had cryopreserved homograft conduits for the initial repair. Sinzobahamvya et al. [10] had made a similar observation in their study of 35 patients. The decision regarding the type of right ventricle to pulmonary artery connection surgery was at the discretion of the attending surgeon. Fifty percent of the patients of this study underwent conduit reoperations in a mean period of $83.63 \pm 62.9$ months (range 10-166). In spite of the reported high (50\%) incidence of conduit reinterventions, the excellent result of no late mortality may be due to the predominant use of homograft. Conduit replacement is eventually necessary in all cases because of homograft valvular stenosis due to shrinkage, distal anastomosis stenosis, conduit calcification, proximal hood aneurysm and somatic outgrowth [11]. Rajasinghe et al. [12] and Tlaskal et al. [13] in their studies of longterm follow-up of PTA after surgical correction reported a similar high incidence of conduit reoperations. In PTA type A1 and A2, Barbero-Marcial et al. [14] and Nemoto et al. [15] have described alternative techniques of right 
ventricle to pulmonary artery continuity established by direct anastomosis. This has potential for the right ventricular outflow tract growth and had a low incidence of surgical reinterventions of right ventricular outflow tract. Recent studies by Raisky et al. [16] and Xu and Shen [17] concluded that repair of PTA by direct anastomosis of right ventricle to pulmonary artery continuity does not increase mortality and morbidity but decreases the need for reinterventions. The 4 patients who had moderate truncal valve regurgitation in our study had their truncal valve repaired in the primary stage. Kaza et al. [18] in one of the largest series of truncal valve repair emphasized that truncal valve repair should remain the primary option. One of the 4 had to undergo valve replacement 9 years later due to persistent severe regurgitation.
The limitations in this study were the small number of the study size and the preferred surgical choice of using homograft. Further studies of a larger study size are needed to draw significant conclusions.

\section{Conclusion}

Our data showed that complete repair of PTA in the neonatal and early infancy period was the treatment with the best potential for survival. Homograft remains one of the conduits of choice to establish continuity between the right ventricle and pulmonary artery in spite of the high incidence of conduit redo operations.

\section{References}

$>1$ Schofield DE, Anderson RH: Common arterial trunk with pulmonary atresia. Int J Cardiol 1988;20:290-294.

-2 Yoskizato T, Julsrud PR: Truncus arteriosus revisited: an angiographic demonstration. Pediatr Cardiol 1990;11:36-40.

>3 McGoon DC, Rastelle GC, Ongley PA: An operation for the correction of truncus arteriosus. JAMA 1968;205:69.

4 McGoon DC, Wallace RB, Danielson GK: The Rastelle operation: its indication and results. J Thorac Cardiovasc Surg 1973;65:865.

$>5$ Singh AK, De Leval MR, Pincott JR, Stark J: Pulmonary artery banding for truncus arteriosus in the first year of life. Circulation 1976;54:17-19.

-6 Haniev FL, Heinemann NK, Jonas RA, Mayer JE, Cook N, Wessel DL, Castaneda AR: Repair of truncus arteriosus in the neonate. J Thorac Cardiovasc Surg 1993;105:10471056.

$>7$ Kanstantinov IE, Karamlov T, Blackstone EH, Mosca RS, Lofland GK, Caldarone CA, Williams WG, Mackie AS, McGrindle BW: Truncus arteriosus associated with interrupted aortic arch in 50 neonates: a Congenital Heart Surgeons Society Study. Ann Thorac Surg 2006;81:222-223.
-8 Gober V, Berdt P, Pavlovic M, Pfamatter JP, Carrel TP: Adverse midterm outcome following RVOT reconstruction using the Contegra valved bovine jugular vein. Ann Thorac Surg 2005;79:625-631.

9 Clarke DR, Campbell DN, Bishop DA: Homograft for congenital heart disease; in Kron IL (ed): Cardiac Surgery: State of the Art Reviews. Philadelphia, Hanley \& Belfus, 1989, vol 3, pp 363-379.

10 Sinzobahamvya N, Boscheinen M, Blaschczoc HC, Kallenberg R, Photiadis J, Haun C, Hraska V, Asfour B: Survival and intervention after neonatal repair of truncus arteriosus with valved conduit. Eur J Cardiothorac Surg 2008;34:732-737.

11 Bove EL, Beekman RH, Snider AR, Callow LB, Underbill DJ, Rocchini AP, Dick M, Rosenthal A: Repair of truncus arteriosus in the neonate and young infant. Ann Thorac Surg 1989;47:499-506.

12 Rajasinghe HA, McElhinney DB, Reddy VM, Mora BN, Hanley FL: Long-term follow-up of truncus arteriosus repaired in infancy: a twenty-year experience. J Thorac Cardiovasc Surg 1997;113:869-879.
13 Tlaskal T, Chaloupecky V, Hucin B, Gebauer R, Krupickova S, Reich O, Skovraneck J, Tax $\mathrm{P}$ : Long-term results after correction of persistent truncus arteriosus in 83 patients. Eur J Cardiothorac Surg 2010;37:1278-1284.

14 Barbero-Marcial M, Riso A, Atlk E, Jatene A: A technique for correction of truncus arteriosus types I and II without extra cardiac conduits. J Thorac Cardiovasc Surg 1990;99: 364-369.

15 Nemoto S, Ozawa H, Sasaki T, Katsumata T, Kishi K, Okumura K, Mori Y: Repair of persistent truncus arteriosus without a conduit: sleeve resection of the pulmonary trunk from the aorta and direct right ventricle-pulmonary artery anastomosis. Eur J Cardiothorac Surg 2011;13:278-284.

16 Raisky O, Ali WB, Bajolle F, Marini D, Metton O, Bonnet D, Sidi D, Vouhe PR: Common arterial trunk repair: with conduit or without? Eur J Cardiothorac Surg 2009;36:675682.

$17 \mathrm{Xu}$ ZW, Shen J: Repair of truncus arteriosus: choice of right ventricle outflow reconstruction. J Card Surg 2010;25:724-729.

- 18 Kaza AK, Burch PT, Pinto N, Minich LL, Tani LY, Hawkins JA: Durability of truncal valve repair. Ann Thorac Surg 2010;90:13071312. 